\title{
ABOUT THE INDIVIDUAL PRODUCTIVITY OF THE FRESHWATER SHRIMP ATYAEPHYRA DESMARESTI MILLET
}

\author{
M.L. Fidalgo \\ Instituto de Zoologia, Faculdade de Ciências. 4000 Porto, Portugal.
}

Palabras clave: Individual growth, individual productivity, ${ }^{14} \mathrm{C}$ labelling foods.

RESUMEN

\section{LA PRODUCTIVIDAD INDIVIDUAL DEL CRUSTACEO DE AGUA DULCE ATYAEPHYRA DESMARESTI MILLET}

En este estudio se pretenden obtener algunos datos acerca de la productividad individual de A. desmaresti en el campo y en el laboratorio, en relación con la temperatura y el alimento suministrado a los animales.

Datos anteriores se refieren a animales pertenecientes a la misma cohorte y pesca, y fueron recogidos en un área tranquila afectada por las mareas a unos $20 \mathrm{~km}$. de la desembocadura del rio Duero (Portugal).

Basandose en las curvas de crecimiento de $A$. desmarest $i$ ha sido posible estimar la tasa de crecimiento de los animales en el campo. Estos resultados fueron expresados en unidades de longitud $(\mathrm{mm})$, que se transformaron en unidades de peso seco (mg). Esta transformación se realizó considerando la relación existente entre los valores de peso seco y los de la longitud total del cuerpo de los animales, usando la ecuacion:

InW $=-0,49+1,14 \mathrm{~L}$; donde $\mathrm{W}$ es el peso seco $(\mathrm{mg})$ y L la longitud total del cuerpo $(\mathrm{mm})$.

De esta manera fue posible evaluar la tasa decrecimientode «animales inmaduros», machos y hembras en el area muestreada.

Con el proposito de obtener datos acerca de la productividad individual en el laboratorio se realizaron experimentos usando animales recogidosen el río Duero y pertenecientes a la misma poblacion.

Durante el periodo experimental los animales fueron sometidos a un fotoperiodo constante $(6.00 \mathrm{a} . \mathrm{m} .-8,00 \mathrm{p} . \mathrm{m}$.) y a diferentes temperaturas $\left(12^{\circ} \mathrm{C}\right.$ y $\left.20^{\circ} \mathrm{C}\right)$, y fueron alimentados con microalgas marcadas con $14 \mathrm{C}$, lodo(1), tetramin(2) y una dieta compuesta por $50 \%$ de mud y $50 \%$ de tetramin.

\section{INTRODUCTION}

The purpose of this research work is to evaluate the contribution of $A$. desmaresti to its biotic community as well as to estimate its eventual interest as food for animals belonging to higher trophic levels.

In this context we carried out some experiments in order to estimate the amount of the incorporated organic matter in the animals'body after supplying to them some ${ }^{14} \mathrm{C}$ labelled foods.

Besides the experiments designed to evaluate the individual productivity in the laboratory we also at- tempt to obtain some data about individual productivity in the field. And this purpose was reached with basis on growth curves of animals which were collected monthly or biweekly in River Douro and we attempted to convert growth values expressed in length units $(\mathrm{mm})$ into dry weight units $(\mathrm{mg})$ on the basis of a regression equation described in a previous paper (Fidalgo, 1983).

Thus, it was possible to evaluate the individual productivity of «immature animals,), males and females.

(1) Mud esta compuesto por materia orgánica viva y muerta, asi como materia inorgánica.

(2) Tetramin es un alimento usado en acuicultura para peces y contiene aproximadamente $49 \%$ de proteinas. $36 \%$ de hidratos de carbono, y 6\% de lípidos, y su valor calorífico es de $5 \mathrm{cal} / \mathrm{mg}$ de materia orgánica (Fidalgo, 1985).

Limnetica 3: 197-203 (1987)

(C) Asociacion Española de Limnologia, Madrid. Spain 


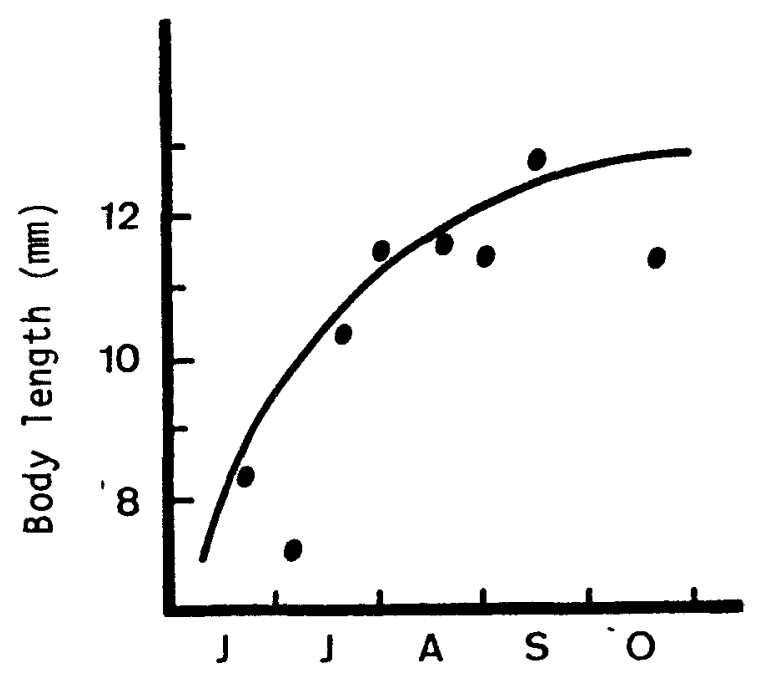

Months

Fig. 1.- Individual growth of «immature animals» in the field. Crecimiento individual de «animales inmaduros» en el campo.

\section{MATERIAL AND METHODS}

The biological material studied was made up of freshwater shrimps, A. desmaresti, from the River Douro (Portugal). The specimens were collected with a net from an area still influenced by the tides, about $20 \mathrm{~km}$ from the mouth of the river.
Animals used in growth study were collected in the prospected area biweekly or monthly according to the season of the year.

Based on these periodic samplings we attempt to study animal's growth in the field and this study was carried out from June 1982 to July of the next year.

Thus, it was possible to study the growth of shrimps from immature phase to adult one (fig. I and fig. 2). As we already referred we converted growth values expressed in length units $(\mathrm{mm})$ into dry weight units $(\mathrm{mg})$ and this transformation was made by using the regression equation: $1 \mathrm{nW}=0.49+0.14 \mathrm{~L}$ indicated in Fidalgo (1983). In this way, it was possible to estimate the productivity of «indifferentiated ani$\mathrm{mals}$ (table 1) as well as that of males and females (fig. 3).

In the case of females we considered not only the somatic growth but also egg production. So, we had to estimate the dry weight of eggs produced by one female, during the reproductive period. Such estimation was made having in mind the mean value of fecundity (Fidalgo, 1985) and considering that one egg weighs about $0.015 \mathrm{mg}$. This value was obtained by weighing 10 samples of 100-200 eggs.

Experiments designed to the estimation of the individual productivity of A. desrnaresti in the laboratory were carried out in the Laboratory of Limnology at the Max Planck Institut for Limnology at Plön (F.R.G.).

Such experiments were run in August and September 1981 and in September and October 1982.

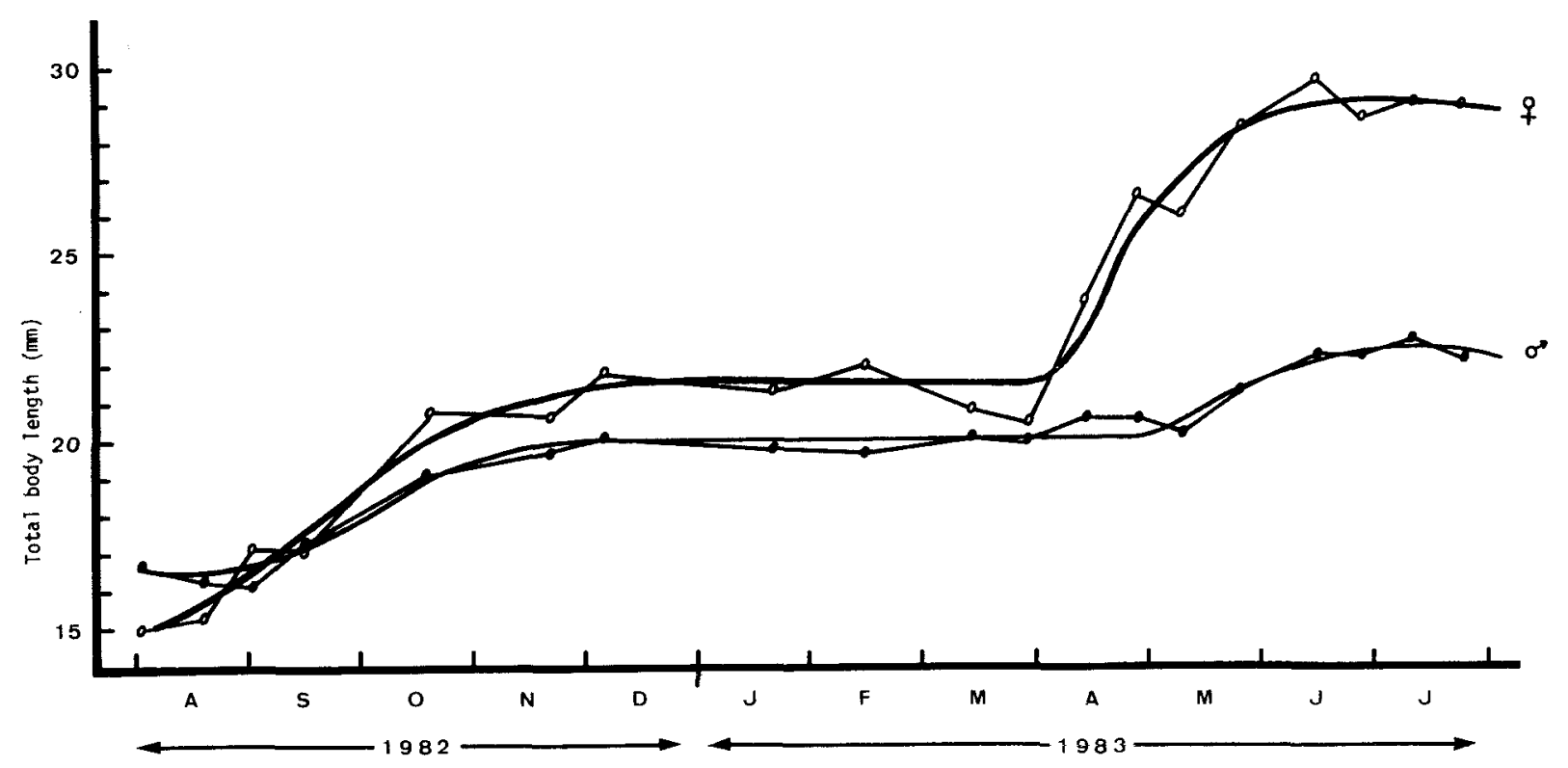

Fig. 2.- Individual growth curves of males and females in the field.

Curvas de crecimiento individual de machos y hembras en el campo. 


\begin{tabular}{|c|c|c|c|}
\hline & $\begin{array}{l}\text { "iminature animals" } \\
\text { (ug dry weight/h) }\end{array}$ & 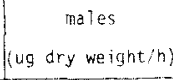 & $\begin{array}{c}\text { females } \\
\text { (ug dry weight } / \mathrm{h})\end{array}$ \\
\hline June-July & ก. $8 \%$ & - & - \\
\hline August-September & 0.44 & 0.95 & 2.08 \\
\hline October-November & $-\ldots$ & 1.61 & 2.78 \\
\hline Decenber-March & $\ldots$ & 0.00 & 0.00 \\
\hline April-Juty & $-\ldots . .$. & 1.37 & 7.44 \\
\hline
\end{tabular}

Table I.- Individual productivity of $A$ desmarest in its habitat Productividad individual de $A$. desmarestien su habitat.

\begin{tabular}{|c|c|c|c|}
\hline \multirow{2}{*}{ Food } & \multirow{2}{*}{$\begin{array}{l}\text { Temp. } \\
\left({ }^{\circ} \mathrm{C}\right)\end{array}$} & \multicolumn{2}{|c|}{$X \pm S . D$} \\
\hline & & $\begin{array}{l}\text { ugfomindidh } \\
\text { ug/a-2-1/4 }\end{array}$ & 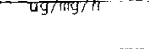 \\
\hline Microaigde & $\begin{array}{l}12 \\
20\end{array}$ & $\begin{array}{c}4.59 \pm 5.08 \\
(n=92) \\
12.52 \pm 14.62 \\
(n=80) \\
\end{array}$ & $\begin{array}{c}1.26 \pm 1.16 \\
(n=92) \\
3.74 \pm 2.82 \\
(n=80)\end{array}$ \\
\hline Tetramin & $\begin{array}{l}12 \\
20\end{array}$ & $\begin{array}{c}1.00 \pm 0.43 \\
(n=5) \\
2.01 \pm 2.89 \\
(n=5)\end{array}$ & $\begin{array}{c}0.38 \pm 0.12 \\
(n=5) \\
0.42 \pm 0.37 \\
(n=5)\end{array}$ \\
\hline $\begin{array}{l}50 \% \text { tetramin: } \\
50 \% \text { mud }\end{array}$ & $\begin{array}{l}12 \\
20\end{array}$ & $\begin{array}{c}32.40 \pm 28.58 \\
(n=6) \\
54.07 \pm 43.30 \\
(n=6)\end{array}$ & $\begin{array}{c}13.80 \pm 11.91 \\
(n=6) \\
16.13 \pm 6.91 \\
(n=6)\end{array}$ \\
\hline Mud & $\begin{array}{l}12 \\
20\end{array}$ & $\begin{array}{c}41.60 \pm 37.35 \\
(n=6) \\
54.83 \pm 44.25 \\
(n=6)\end{array}$ & $\begin{array}{c}17.46 \pm 15.53 \\
(n=6) \\
11.78 \pm 10.41 \\
(n=6)\end{array}$ \\
\hline
\end{tabular}

Table 2.- Mean values of individual productivity of $A$ desma resti according to food and temperature.

$\overline{\mathrm{X}}=$ mean value: $\mathrm{S} . \mathrm{D} .=$ standard deviation; $\mathrm{n}=$ number of determinations.

Valores medios de productividad de 1 desmaresil en relación con el alimento y la temperatura

The shrimps were also collected from River Douro and they were carried to the referred laboratory where they kept (in stock aquaria) at $12^{\circ} \mathrm{C}$ or $20^{\circ} \mathrm{C}$ according to the kind of experiment in which they would be used later on.

In these experiments mud that supplied to the animals as well as the water used in the aquaria were collected from Shochsee which is located in the surroundings of the Max Planck lnstitut at Plön.

The estimation of dry weight of foods was done after filtering them through glass fiber filters which were dried in the oven $\left(2\right.$ hours, $\left.105^{\circ} \mathrm{C}\right)$ and preweighted.

Animals were also dried in the oven for 2 hours at $105^{\circ} \mathrm{C}$

Weighings were done on a Cahn microbalance (model 25) whose accuracy is $0.1 \mu \mathrm{g}$.

Whenever we wished to estimate the amount of the organic matter in foods or in the animals the respecti-

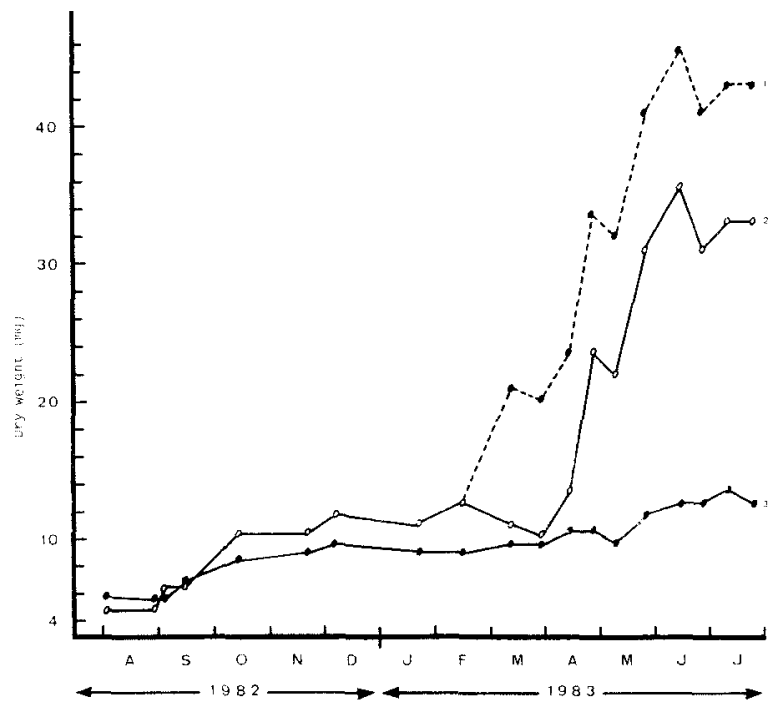

Fig. 3.- Individual productivity of $A$ desmarest $i$ in its habitat. 1 = ovigerous females: 2 = not ovigerousfemales; 3 = males. Productividad individual de A. desmaresti en su habitat.

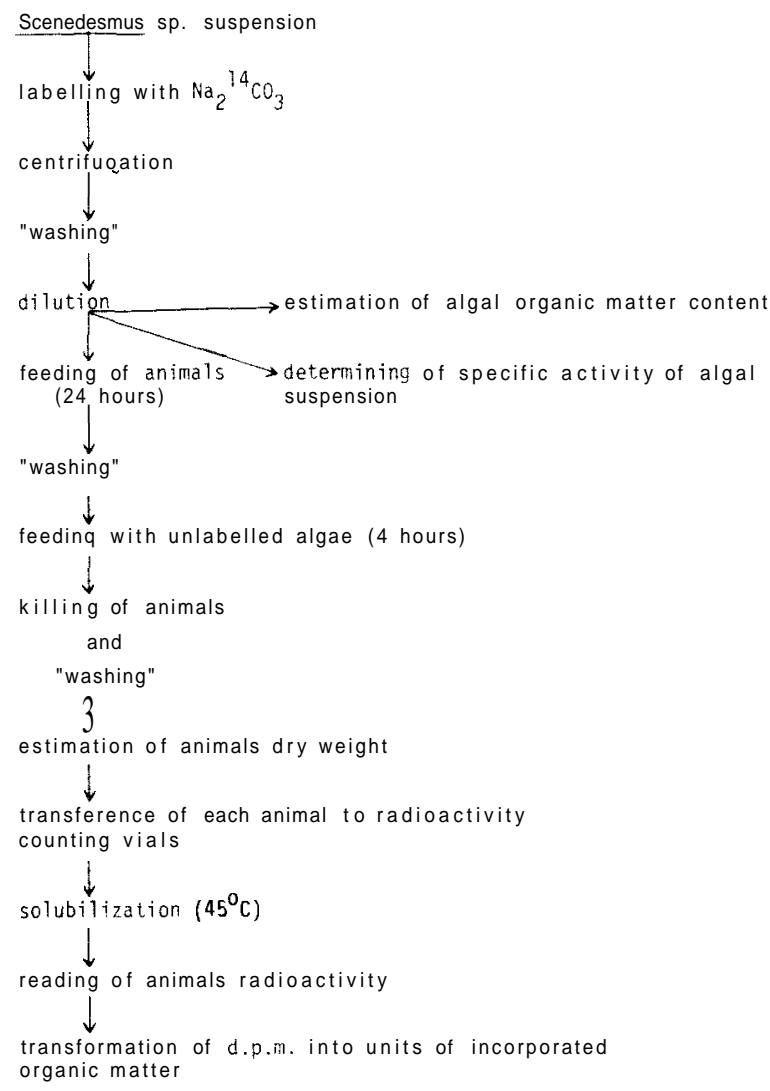

Fig. 4.- Scheme of tile experimental performance. Esquema del trabajo experimental. 


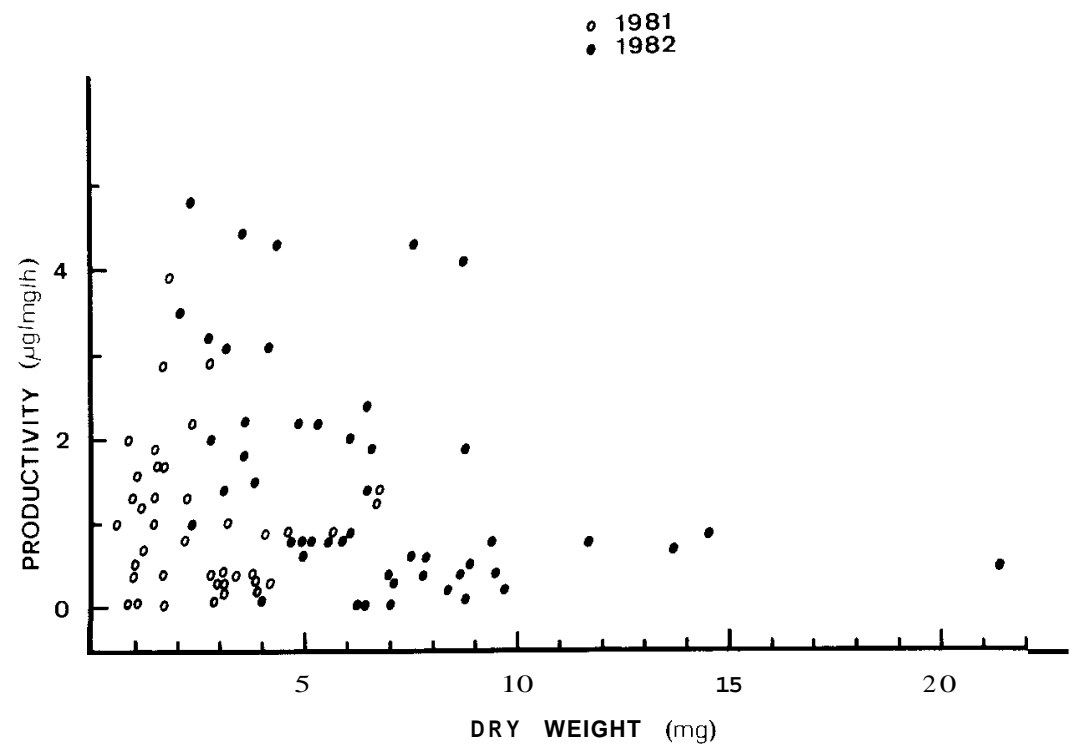

Fig. 5.- Individual productivity of $A$. desmaresti at $12^{\circ} \mathrm{C}$

Productividad individual de $A$. desmarest $i$ a $12^{\circ} \mathrm{C}$

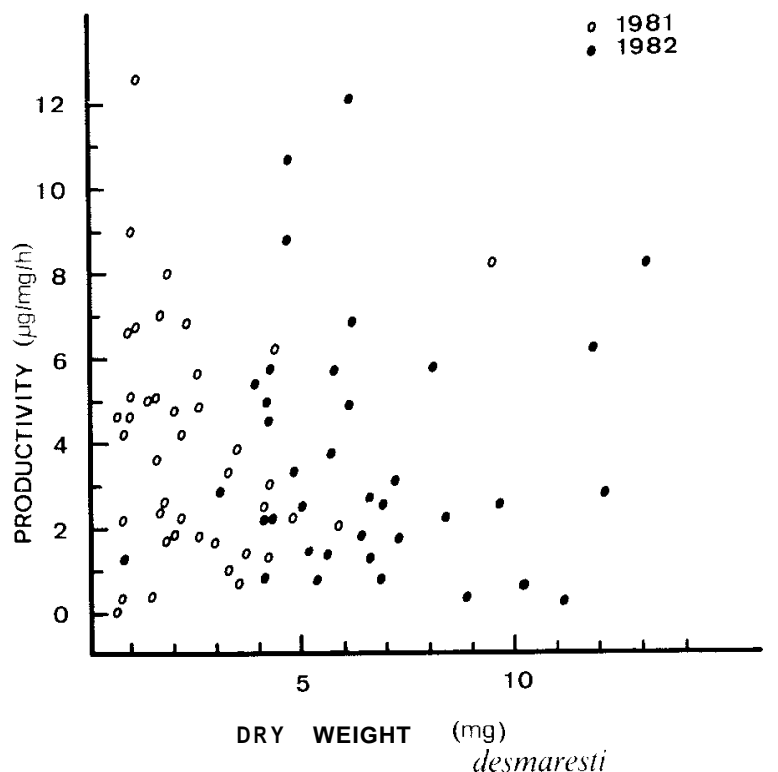

Fig. 6.- Individual productivity of A. at $20 " C$

Productividad experimental de $A$. desmares $t i$ a $20^{\circ} \mathrm{C}$

ve samples were burned in a mufle $\left(6\right.$ hours, $\left.550^{\circ} \mathrm{C}\right)$ and glass fiber filters that we used for filtering foods were previously burned in the mufle and preweigthed.

Experiments designed to estimate the amount of organic matter accumulated in animals'tissues were done according to the scheme presented in fig. 4 .
The labelling of microalgae (monoculture of Scenedesmus sp.) was done the night before of an experiment and it consisted in innoculating ${ }^{14} \mathrm{C}$ in the culture medium where algae grew up for about 16 hours more. Thus, we expected to guarantee the homogeneous labelling of microalgae and, consequently to avoid the introduction of some errors coming from the incomplete ${ }^{14} \mathrm{C}$ labelling which would have some effects on the estimation of the productivity values.

After labelling the algae, but before they were supplied to the animals, they were centrifuged, «washed» and diluted in lake water previously filtered.

From this algal stock suspension 3 samples were taken in order to estimate the organic matter content of microalgae. We also took 2 sub-samples of $0.5 \mathrm{ml}$ for estimating the specific activity of the algae supplied to the animals. These two sub-samples were filtered on membrane filters $(0.45 \mathrm{um})$ which were transferred individually to the counting vials.

The respective radioactivity was counted, for $5 \mathrm{mi}$ nutes, in a liquid scintillation counter (Packard, Tricarb $460 \mathrm{cD}$ ). The specific activity of the organic matter contained in the algae was estimated with basis on the radioactivity of those sub-samples and on the organic matter content of algae.

Mud and tetramin were ${ }^{14} \mathrm{C}$ labelled by means of the adition of a certain volume of ${ }^{14} \mathrm{C}$ labelled algal suspension which had been previously labelled as described above.

Thus, the night before supplying mud and tetramin to the animals, about $2 \mathrm{ml}$ of ${ }^{14} \mathrm{C}$ labelled algae were added to $50 \mathrm{ml}$ of mud or tetramin suspensions. 
Tested foods were supplied to the animals on glass fiber filters which were put in the experimental aquaria and each filter contained about $40 \mathrm{ml}$ of food suspensions. Filter were put in containers with about $600 \mathrm{ml}$ of lake water previously filtered and constantly aerated and 3 or 4 animals belonging to different size clases were put in each experimental aquarium.

Experimental aquaria were kept, some at $12^{\circ} \mathrm{C}$ and others at $20^{\circ} \mathrm{C}$, and during the experimental period animals fed ${ }^{14} \mathrm{C}$ labelled foods.

The experimental period lasted about 24 hours and, in some cases, animals fed on ${ }^{14} \mathrm{C}$ labelled microalgae were subsequently fed upon unlabelled microalgae for about more 4 hours to remove labelled algae from the gut.

However, considering that the obtained results in both cases did not show significant differences we decided to supply to the animals only labelled algae for 24 hours.

At the end of an experiment animals were killed, "rinsed» and dried in the oven in order to estimate the respective dry weight. Then, they were transferred individually to the scintillation counting vials and they were covered with one drop of destilled water. Each animal was also covered with $1 \mathrm{ml}$ of soluene 350 (solubilizer of tissues). The tissues solubilization took place overnight at $45^{\circ} \mathrm{C}$. Afterwards, $15 \mathrm{ml}$ of toluene (scintillator cocktail) were added to each vial.

The radioactivity of the animals was counted, for 5 minutes, in the liquid scintilation counter already mentioned.

Calculations concerning the estimation of the amount of the organic matter incorporated by the animals, during the experimental period, were made by means of the following equation:

$\mathrm{C}=\mathrm{Cr} \times \mathrm{R}$

Were $\mathrm{C}$ means the dry weight of the organic matter contained in the tested animals $(\mu \mathrm{g}), \mathrm{Cr}$ represents the inverse of the specific activity of the organic matter contained in the labelled algae ( $\mu \mathrm{g}$ of organic matter / d.p.m. ${ }^{1}$ and $R$ is the radioactivity of the animals (d.p.m.).

Productivity values were expressed in $\mu \mathrm{g}$ of incorporated organic matter/animal/ hour. The transformation of former units into the latter was based upon the estimation of the dry weight of the animals after their total body length (fig. 1) and considering that $A$. desmaresti contains about $82 \%$ of organic matter (Fidalgo, 1985).

\section{RESULTS}

The obtained results can be seen in tables 1 and 2 .

Estimation of productivity of A. desmarest $i$ by using growth values registered in the field.
Keeping in mind the obtained results (table 1) we are led to state that the values of productivity of juvenile animals are lower than that of adult ones, during most of the year, more precisely in spring and summer months.

On the other hand, in winter months length of males did not show any detectable increase and that of females increased by $0.2 \mathrm{~mm}$. and this corresponds to a very low value of productivity.

We have to point out that age is one of the factors which is responsable for the variability of this term of the energy budget.

As it is known, juvenile animals usually accumulate a higher amount of organic matter when compared with adult ones and this will correspond to higher values of productivity of former animals.

However. our results are not in agreement with this statement and we thought that our findings can be attributed, very likely, to the method how these data were estimated.

As we already referred, such results were estimated by measuring the animals' length and we would like to emphasize that this method is not a rigorous one.

Some authors (Cole \& Waugh. 1959), cited by Katre \& Reddy (1977), state that growth estimation based upon length or animals' body diameter should not be considered as a real growth index as sometimes animals' weight increases but their body length does not.

By analysing fig. 3 we can see immediately that females productivity is higher than that of males and this is particularly visible from March to July.

In fact, this period of the year corresponds to the reproductive period and during this season of the year the growth rate of females is clearly higher than that of males (fig. 2).

In spring and summer months an increase of $\mathbf{3} \mathrm{mg}$ and $20 \mathrm{mg}$ was registered in the dry weight of males and females respectively.

We would like do emphasize that considering not only the somatic growth, but also the production of eggs we can state that females productivity is much higher than that of males (fig. 3).

\section{Experimental estimation of the individual productivity} of $\mathrm{A}$. desmarest $i$ in the laboratory

As we can see in table 2 , the values of productivity obtained with mud and with one diet composed by $50 \%$ of mud and $50 \%$ of tetramin were higher than those obtained either with tetramin or microalgae.

Keeping in mind the obtained results we are led to hypothesize (i) that mud and tetramin suspensions were not homogeneously ${ }^{14} \mathrm{C}$ labelled and (ii) we also suggest that shrimps prefer tetramin to microalgae and microalgae to mud. 
However, in doing the calculations of productivity we assume that mud and tetramin suspensions are homogeneously ${ }^{14} \mathrm{C}$ labelled and this is very difficult owing to (i) the small volume of the ${ }^{14} \mathrm{C}$ labelled microalgae used to labelling tested foods and (ii) to the difficulties of mud and tetramin in incorporating carbon.

As we already mentioned with regard to the labelling of mud and tetramin we jus used $2 \mathrm{ml}$ of ${ }^{14} \mathrm{C}$ labelled algae. This volume was added to $50 \mathrm{ml}$ of mud or tetramin suspension.

Thus and because only algae were labelled we can easily understand that in the case of animals prefer algae to the foods this fact will represent an overestimation of productivity. And the inverse will be observed if animals prefer mud or tetramin to algae.

Because of the low number of the obtained results with not algal diets we just show the scatter diagram with respect for productivity values obtained with microalgae according to temperature.

We do not show the scatter diagram with respect for the values of the productivity expressed in $\mu \mathrm{g}$ of organic matter accumulated / animal / hour because we think that values expressed in $\mu \mathrm{g}$ of organic matter incorporated / $\mathrm{mg}$ of organic matter in the animal body / hour (fig. 5 and fig. 6) are more advantageous, under a comparison point of view, than the former.

Despite the variability of the obtained results we can state that the mean value of productivity corresponding to animals kept at $12^{\circ} \mathrm{C}$ is lower than the mean value corresponding to animals kept at $20^{\circ} \mathrm{C}$, with exception of those animals fed on mud (table 2).

In spite of the variability of the productivity values we can see there is no difference between values estimated in 1981 and those obtained in 1982. for that reason we are led to consider them as replica and not merely accidental ones.

Based on the productivity values corresponding to animals kept at $20^{\circ} \mathrm{C}$ and fed on microalgae we state that shrimps accumulate about $0.4 \%$ of the respective dry weight per hour, i.e., about $10 \%$ per day. In our opinion, those values suggest a quite good rate of incorporated organic matter and we can not forget that dry weight of tested animals ranged between $0.6 \mathrm{mg}$ and $21.5 \mathrm{mg}$.

I-Iowever. by comparing the mean value of the rate of feeding (estimated by suplying $32 \mathrm{P}$ labelled microalgae) (Fidalgo, 1985) with those of productivity we conclude that they are incompatible, because productivity values are higher than the values of the feeding rate either at $12^{\circ} \mathrm{C}$ or at $20^{\circ} \mathrm{C}$.

In our opinion productivity values obtained after 24 hours correspond to an overestimation of net productivity, as that period of time although it is enough to allow a good adaptation of animals to the experi- mental conditions but it will not be enough to allow metabolic equilibrium in the animals.

However, the variability of the obtained results should not be attributed to the inaccuracy of the employed method. On the other hand, such variability it is not suprising because of individual variability and productivity depends on several factors (age, sex, moulting cycle, etc.)

In fact, we used animals belonging to different size classes from «immature animals» to adult ones - males and females.

The age of the animals is a factor which should bc considered in the interpretation of the productivity values. As it is known young animals incorporate more organic matter than adults and consequently the productivity of the former will be higher than that of latter.

Indeed in fig. 5 and 6 and particularly in fig. 5, we can see a clear decrease in the productivity values as the size of animals increases.

\section{DISCUSSION OF THE RESULTS}

By comparing the values of productivity in the field with those estimated in the laboratory we can see that former values are usually lower than latter ones, with exception of those animals fed on tetramin.

We are convinced that such a stricking finding is related to the selective ingestion of tetramin to ${ }^{14} \mathrm{C}$ labelled algae as well as to the limitations of the ${ }^{14} \mathrm{C}$ labelling foods.

In fact, bearing in mind that tetramin is a food with a very high content in organic matter (about 95\%) and that the organic matter content in mud is rather low we are led to point out that such higher values of productivity in the field can be explained by means of the hypothesis already mentioned. more precisely not homogeneous ${ }^{14} \mathrm{C}$ labelling foods and selective ingestion of tetramin relatively to ${ }^{14} \mathrm{C}$ labelled algae.

\section{CONCLUSIONS}

With the data obtained in this study the following conclusions can be drawn:

By analysing the productivity values of animals in the field we state that, in spring and in summer months. females accumulate more organic matter than males. This difference is still more considerable during the reproductive period because of the fecundity of ovigerous females.

The mean values with respect to individual productivity at $20^{\circ} \mathrm{C}$ and expressed in $\mu \mathrm{g}$ of organic matter incorporated por animal hour arc higher than those corresponding to the animals fed on the same foods but kept at $12^{\circ} \mathrm{C}$. 
Based upon productivity values corresponding to animals kept under laboratory conditions we are led to conclude that. I- desmaresti shows a quite good rate of incorporated organic matter. For that reason we think that $A$. desmaresti can be used as food to animals belonging to higher trophic levels.

In spite of the variability of the productivity values we can see there is no difference between those values estimated in 1981 and those obtained in 1982. For that reason we are led to consider them as replica and not merely accidental ones and the variability of the obtained results should not be attributed to the inaccuracy of the employed method.

In fact, such variability is not surprising because of individual variability and we have to remenber that productivity depends on several factors (age, sex. moulting cycle, etc.).

Based upon our knowledge about the biology of A. desmaresti and the estimated values of feeding rate (Fidalgo, 1985) and by comparing these data with those of productivity obtained in this study we are led to conclude that the estimated values of productivity correspond to an overestimation of this term of energy budget.
For that reason. we think that the employed method does not allow the correct estimation of the individual productivity of this freshwater shrimp.

\section{REFERENCES}

Fidalgo, M.L., 1983. Oxygen consumption in Atvaephyra desmaresti Millet (Crustacea. Decapoda, Natantia). Puht. Inst. Zool «Dr. 4. Nobre», 176.

Fidalgo. M.L., 1985. Contribução para o conhecimento da biologia de Atyaephyra desmaresti Millet. Alguns aspectos da dinàmica populacional e do balanço energẽtico. Tese de doutoramento apresentada à Faculdade de Ciências da Universidade do Porto

Katre, S. \& Reddy, S.R., 1977. Laboratory studies on food intake, grouth and convertion efficiency of Palaemon lamarrei in relation to body size. Aquaculture, 11:247-261.

Sorokin, JU. 1., 1968. The use of ${ }^{14} \mathrm{C}$ in the study of nutrition of aquatic animals. Mitt. Int. Ver. Limnol., 16: 1-41.

Sorokin, JU. I. \& Panov, D.A., 1966. The use of ${ }^{14} \mathrm{C}$ for the quantitative study of the nutrition of fish larvae. Int. Rev. ges. Hydrobiol., 51 (5): 743-753. 